\title{
Social media as a means to access millennial wine consumers
}

\author{
by Fernandez, R.F., Vriesekoop, F. and Urbano, B.
}

Copyright, Publisher and Additional Information: This is the author accepted manuscript. The final published version (version of record) is available online via Emerald Publishing Please refer to any applicable terms of use of the publisher.

DOI: https://doi.org/10.1108/IJWBR-08-2016-0030

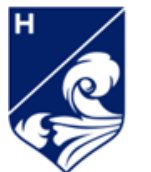

Harper Adams University 


\section{Social Media as a Means to Access Millennial Wine} Consumers

\begin{tabular}{|r|l|}
\hline Journal: & International Journal of Wine Business Research \\
\hline Manuscript ID & IJWBR-08-2016-0030.R2 \\
\hline Manuscript Type: & Research Article \\
\hline Methods: & Surveys, Regression \\
\hline Topics: & Wines, Consumers \\
\hline \multicolumn{3}{c}{} \\
\multicolumn{3}{c}{ SCHOLARONE } \\
\multicolumn{3}{c}{ Manuscripts $^{M}$}
\end{tabular}


3 Abstract

4 Purpose

5 The purpose of this research is to gain insights of the use of social media (SM) in the

6 wine industry. From the theoretical viewpoint to analyze wineries' social media

7 segmentation, targeting and positioning (STP) to help the wine industry to improve the

8 effectiveness of SM communication.

9 Design/methodology/approach

10 An observational study of Spanish wineries' SM presence and traffic was carried out 11 during a three-month period in 2013 and repeated in 2016. During this period a 12 questionnaire was distributed to 196 wineries. Logistic regression was used to model the 13 dichotomous outcome variable of whether a winery "does" or "does not" utilise SM. 14 Additionally, leader wineries were interviewed in April/May 2016 about SM 15 segmentation, targeting and positioning (STP).

\section{Findings}

17 The results show that most wineries are starting in SM without a well-defined strategy.

18 The presence of a webpage is significantly related to the use of SM. SM wineries do not 19 segment and can take advantage of digital targeting strategies.

\section{Practical implications}

21 Segmentation and targeting SM can improve the effectiveness of the winery SM 22 activities as well as the winery competitiveness in the wine industry.

\section{Originality/value}

24 This research is a first step in understanding the value of segmentation SM to reach 25 millennial consumers and the importance of targeting to improve the effectiveness of 26 winery on SM.

27 Keywords ICT, Spanish wineries, digital wine targeting and positioning strategy, wine 28 SM segmentation.

29 Article Classification Research paper

30

31 Introduction

32 Researchers and marketers emphasize the importance of SM as an easy, low cost 33 communication option that provides an immediate connection with a large number of 34 consumers (Dolan et al., 2016; Fiore et al., 2016; Forbes et al., 2015; Thach and Lease, 
2014). However, there is still a long way to go for the wine industry with regards to SM management before it becomes a truly efficient marketing tool for the wine industry (Laverie et al., 2011; Vinography, 2016).

It is generally accepted, even by wineries, that SM like Facebook and Twitter are a means to access millennial wine consumers. Nevertheless, the literature remarks that the younger generations are embracing SM (Leigon, 2011). Facebook and Twitter are more used by Generation X and baby boomers (Leigon, 2011; Reyneke et al., 2011). Little research has been undertaken to understand the segmentation and specific targeting of marketing practices using SM to improve the competitiveness of wineries. Even less is known about the effectiveness of SM communications in order to access target groups like millennial wine consumers.

\section{Background}

\subsection{Wine and Social Media}

The 2008 Global Financial Crisis did cause many consumers to move downmarket, which included purchasing wines that were less expensive, and from a greater variety of wine regions (Gokcekus and Finnegan, 2013). This coincided with a surge in the use of the internet and SM, which significantly expedited information sharing (Zickuhr, 2010; Wilson and Quinton, 2012). SM has become an important tool that connects one third of the world's population (Nelson Field and Taylor, 2012), more than one billion people use Facebook and more than 280 million are active users on Twitter each month (Stieglitz et al., 2014). SM offers advertisers access to eighty per cent of global consumer expenditures, a US\$29 trillion market (Nuttney, 2010) and more than 15 million brands are registered on Facebook (Koetsier, 2013). Wine and associated business received its fair share of increased exposure from this surge in SM-based interests, e.g. wine is the most frequently searched beverage on the web and is being talked about daily and hourly by an international and diverse tweeting population (Thach and Rosenberg, 2011; Storchmann, 2012; Wilson and Quinton, 2012). Many wine consumers pay attention to the views and thoughts of "similar others" to seek experts' opinions (Gokcekus and Finnegan, 2013; Cialdini and Goldstein, 2004); while the UK's leading wine critic "tweets" regularly on Twitter who has more than 24,000 followers (Reyneke et al., 2011). A study carried out by Szolnoki et al. (2014) showed $75 \%$ of SM users admitted that wine-associated SM interactions can influence their purchases and increase spend on an individual wine purchase. Furthermore, their study 
also revealed that fans are $41 \%$ more likely to recommend those wines. It is estimated that $90 \%$ of wine drinkers use Facebook 6.2 hours per week, and Google Analytic-2012

71 shows that wineries are the third most popular subject on Pinterest. The number of wine 72 blogs is now estimated to be around 1,300 (Thach and Lease, 2014). While a keen 73 interest in wine-related SM exists.

\subsection{Millennial Generation and Wine Behaviour}

Millennial consumers are defined as: persons born between 1977 and 2000, who are the "children of the baby boomers" (Atkin and Thach, 2012). The most prominent characteristic is their technology savviness and use of that technology in almost every aspect of their lives (Pate and Adams, 2013). Five years ago, they spent on average of 33 hours per week on the internet (Kilian et al., 2012); with 83\% being engaged with online social networking sites (Zickuhr, 2010); and almost all millennials in developed countries have a smart phone (Miller, 2014; Nicholls, 2012). The millennials' interest in technology might explain why many seek out wine groups on Facebook and other social networking sites (Thach and Olsen, 2006).

While the millennials account for a $35 \%$ growth in wine consumption in US (Atkin 86 and Thach, 2012); in both France and Italy overall wine consumption among millennials is decreasing (Charters et al., 2011; Espejel et al., 2011). Red wines appear to be the preferred varietal among US millennials (Olsen et al., 2007; Teagle et al., 2010), however they happily try previously unexplored wines from a range of different countries. Millennials utilize 'alcohol content', 'label imagery' and 'medals won' as points of interest; while older generations utilize 'country of origin', 'vintage' and 'region' as cues to make purchasing decisions (Atkin and Thach, 2012). In this sense, awards and medals, expert scores, and other on-package information all contribute to increasing the probability of choice. In fact, consumers who spend more on wine demand more information (Lockshin and Corsi, 2012).

96 When making purchasing decisions the millennials are especially susceptible to 97 opinions of others (Orth, 2005). They are readily influenced and are often concerned 98 about their own ability to choose the correct wine for the correct occasion (Barber et al., 99 2006). In contrast, Teagle et al. (2010) pointed out that millennials were found to be 100 less risk averse than older wine consumers. Generally, the self-reported wine knowledge 101 by millennials is significantly lower compared to older people (Atkin and Thach, 2012). 102 Millennials rely more on advice from salespersons or waiters, and samples and in-house 
103 displays (Halls et al., 2004). Hussain et al. (2008) found that wine consumption was

104 positively related to age and income.

105

$106 \quad 1.3$ Segmentation and targeting wine social media

107 In a strong competitive market a segment-based positioning strategy can be a 108 competitive advantage and can provide solutions for the selection of an appropriate 109 target group and the definition of a suitable offer (Natter et al., 2008). Viberti et al. 110 (2014) emphasized the ability of SM to achieve a direct contact with a target market 111 characterized by an interest in wine consumption and belonging to a wine community.

112 However, Thach (2010) highlights the lack of scientific studies about the type of 113 consumer who reads and interacts with wine blogs. While Blasius and Brandt (2010) 114 noticed a higher proportion of younger and more educated internet users, Bruwer and 115 Wood (2005) remarked that wine-buying internet users' are mostly men in their mid116 thirties and in a high-income bracket. Apart from those, there is little evidence about 117 who the users of wine SM are.

118 Likewise, little is known about wineries' strategies for segmentation, targeting and 119 positioning (STP) in SM. Capitello et al. (2014) remarked that larger wineries are 120 targeting 'fun', "terroir" and 'quality' to attract potential consumers to their brands; 121 while the rest of the wineries are conveying sophisticated corporate values associated to 122 their brands, especially to young consumers. Capitello et al. (2014) classified wineries' 123 strategies as digital brand orientation and brand involvement, according to the 124 development and positioning of the brand on SM. The wineries that use multiple SM 125 channels, rather than only one or two are more probable to report increases in wine sales 126 (Thach and Lease, 2014). Leigon (2011) defends the ability of SM to communicate 127 directly with sales managers/representatives and distributors.

128 Wineries can take advantage of the surge in SM engagement on Fridays (Dolan et al., 129 2016) and the increase in wine consumption on weekends. Wineries can also post 130 images, mental associations, and lifestyles to target young wine consumers in developed 131 countries (geo-targeting) (Fiore et al., 2016; Wilson and Quinton, 2012). The data 132 provided by users through SM subscription, i.e. Facebook, can serve to segment and 133 access millennial wine consumers and exploit demographic targeting (Bruwer and $\mathrm{Li}$, 134 2007). Google allows business to perform searches on millennials, including 135 millennials' interests on the messages by keywords targeting (Bauer et al., 2011). 136 Internet 'cookies' allows the webhost to send messages/banners of a category of wine 
137 that the user has abandoned to purchase (re-targeting). Behavioral-targeting of a wine 138 consumer and their online fingerprint might allow the user of a digital device to be 139 prompted and send similar contents and advertisements (Barber, 2010). Businesses can 140 also buy internet search hits/occurrences through keywords of wines of interest, or 141 wineries, to receive all the information published about them, which is called semantic 142 priming (Labroo et al., 2008). Despite this, Lockshin and Corsi, 2012, argued that we 143 are still at a very early stage in understanding the best way to use SM in wine 144 marketing.

\section{Research Objectives, Hypotheses and Methods}

The overall objective of the research is to gain insights of the use of SM in the wine industry and to test the wineries SM segmentation and targeting to improve the effectiveness of SM communication, but specifically to:

- Determine the SM strategy among Spanish wineries.

- Analyse the evolution of SM practices among the Spanish wineries.

- Measure the wineries awareness on segmentation and targeting SM.

To direct the research the following hypotheses were tested:

$\mathrm{H}_{1}$ : Most of the wineries are starting in SM without a well-defined strategy. $\mathrm{H}_{2}$ : Wineries engaging in SM have a "digital" history. $\mathrm{H}_{3}$ : Wineries engaging in SM do not segment SM on targeting wine consuming

\subsection{Data collection}

160 This study employed a randomized and stratified sample of 196 wineries in the Spanish 161 wine region of 'Castilla y León' that counts twelve Origin Denomination labels. For a 162 total of 588 wineries in the region at the time of this study, the sample size (196) 163 yielded a $95 \%$ confidence interval with a $7.14 \%$ predicted margin of error.

164 Firstly, the wineries were selected from the Origin Denomination Board's database. 165 Then a survey was conducted to collect wineries data in the light of i) business and ii) 166 SM management (Table 1). The survey was conducted by a mixed method. Some of the 167 business data were collected using the annual directory of Spanish wineries and then 168 completed by phone in 2013 and again in 2016; while some of the data were obtained 169 by observing SM content and activities. For instance: SM activities of wineries on 170 Facebook and Twitter were followed from January to March of 2013; and again for the 
171

172

173

174

175

176

177

178

179

180

181

182

183

184

185

186

187

188

189

190

191

192

193

194

195

196

197

198

199

200

201

same period in 2016 during which Instagram was included (Instagram was not in use by any of the wineries in 2013). Categorical and quantitative data were obtained.

\section{Note to typesetter: Insert Table 1 here}

The study was completed with a qualitative study, consisting of deep interviews with leading Spanish wineries to collect data in the light of i) management, ii) millennial segmentation, and iii) success on SM.

\subsection{Logistic regression model and significance analyses}

SPSS 20.0 software package was used for statistical analyses. Absolute and relative frequencies and accumulated percentages were obtained. To obtain the significant variables to have SM a two-way dependence was calculated. The two-way dependence between the business variable to be explained and the explanatory dichotomous outcome variable, "use" or "do not use" social media by the winery was calculated by means of a chi-squared $\left(\chi^{2}\right)$ test of significance between the items. To accept or reject the hypothesis $H_{0}$, which implies no relation between the variables, the value of the $\chi^{2}$ statistics and the respective $p$-values were considered and dependence was determined in the light of the frequencies expected and obtained and the corresponding residues. For the significant variables obtained, a logistic regression, logit, was used. In the logit model the log odds of the outcome was modelled as a linear combination of the predictor significant business variables. The dataset has a binary response (outcome, dependent) variable called SM, which is equal to 1 if the winery had social media, and 0 otherwise. Logistic regression was used to predict the odds of being a case based on the values of the independent/business variables (predictors). The odds are defined as the probability that a particular outcome is a case divided by the probability that it is a noncase.

$$
\ln \frac{p_{i}}{1-p_{i}}=x_{i} \beta
$$

Where $\mathrm{x}_{\mathrm{i}} \beta$ is the linear probability model with linear combination of explanatory variables $\mathrm{Xi}=[1, \mathrm{X} 1 \mathrm{i}, \mathrm{X} 2 \mathrm{i} \ldots, \mathrm{Xki}]$ with $\mathrm{k}$ explanators and a vector of regression coefficients $\beta_{k}=\left[\beta_{0}, \beta_{1}, \beta_{2} \ldots, \beta_{k}\right]$ as the parameters associated that will be all estimated. Finally, two (for 2013 and 2016) overall logit models were calculated and the 
202 determinant variables to have or not have SM for each year in the wineries was 203 obtained.

\subsection{Profile of the sample}

206 Most of the wineries included in this study were established between 1996 and 2010 207 (57.7\%) while only a few of them (3.6\%) commenced operation before 1949 (Table 2).

208 A third of the wineries were deemed to be small or medium sized wineries $(32.1 \%$ 209 produced less than $250 \mathrm{Hl}$ per year); while $36.7 \%$ of the wineries produced between 250 210 and $2,990 \mathrm{Hl}$ of wine. The remainder of the wineries (31.2\%) achieved an annual 211 production volume in excess of $3,000 \mathrm{Hl}$ of wine per year. A very large proportion of 212 wineries only produced a single type of wine (26\% and $28.6 \%$ produced red and white 213 wines only respectively); while nearly 44\% produce mainly red and/or rosé wines 214 (Table 2). Nearly one quarter of all wineries produced both red, white and rosé wines; 215 which allows them to satisfy a broad range of consumer demands. Although the 216 wineries were family-run business, most of them were 'private limited companies' 217 (64.3\%), or 'public limited companies' (16.3\%). In 2013 two third of the wineries 218 exported their wines; while in 2016 nearly all (98.9\%) were exporting their wines. Most 219 of the wineries operated an independent webpage, $81.03 \%$ in 2016 which was slightly

\section{Research Limitations}

224 One of the limitations of the research is the wineries heterogeneity that biases the 225 sampling due to the geographical approach. The results could vary in another Spanish region or another country. It could be interesting to study other regions or countries. On the other hand, and due to the rapid-development of the technological environment of SM, the results could easily become obsolete although it is still of interest because it could be a first step in the use of technology for wine social media STP.

230

231

\section{Research Results}

2323.1 Social Media Usage

233 Over the three years of this study (2013-2016), a large increase in the use of SM by the 234 wineries was observed, an additional 35 wineries (up from $42.8 \%$ to $60.7 \%$ ) started 235 using SM. In 2013 the only SM sites used by wineries were Facebook and Twitter, 
66.67\% using only Facebook and the rest using both SM sites. By 2016 Facebook was used by $94.12 \%$ of the wineries; Twitter by $56.3 \%$; and Instagram by $19.33 \%$ of the wineries. The prominence of Facebook at the dominating SM site used by the wineries makes sense although some authors recommend using variety and more specific wine SM (Thach and Lease, 2014; Wilson and Quinton, 2012). Facebook is the number one global SM site followed by YouTube, QQ, WhatsApp, Qzone, Twitter, SinaWeibo, WeChat, Google+ and Instagram (Web empresa, 2015; Dolan et al., 2016). Moreover, Facebook is the principal SM in America, Europe, Oceania, part of Asia and Africa; while Twitter is the principal SM in Japan (Web empresa, 2015).

In 2016, 44 wineries (36.97\%) had attracted over 5,000 followers; while in 2013 the number of followers on SM of the same wineries varied from 31 to 4,939. For instance, one winery attracted 307,556 followers on Facebook. Yet another winery attracted 19,400 followers on Twitter and 5,048 followers on Instagram. Among the examples of positive uptake of SM among the wineries there were many wineries with a low number of followers despite the early accomplishment to initiate a SM presence (Table 3). These results confirm the engagement among the fans of wine SM (Dolan et al., 2016). Furthermore, apart from the number of followers that were linked to the SM sites of various wineries; the basic active interaction that followers have with the companies can be visualised through their indication of 'like' versus 'dislike'. In 2013: 53,738 followers clicked "I like it" on Facebook for at least one of the wineries. In 2016: 85,291 followers clicked "I like it" for at least one of the wineries in Facebook per month; while well over 100,000 followers clicked 'like' on Twitter (Table 3).

Of all the SM interactions; 30.1\% and 25.9\% (in 2013 and 2016 respectively) of the companies with an SM presence undertook no activity on their own SM sites with only a very small proportion of companies communicating in access of 50 interactions per month (Table 3). An inefficient use of wineries SM is confirmed at this point, wineries only send information to consumers, without a feedback loop and had not adopted the Wine 2.0 methods (Forbes et al., 2015; Reyneke et al., 2011; Thach and Olsen, 2006; OEMV, 2014). With this in mind a number of leader wineries were approached for their opinion and insight into the use of SM in their companies. The 'Matarromera' winery stressed the importance to communicate directly to consumers to avoid misunderstandings that could damage the company image. The 'Martin Codax' winery, reported that the company uses their SM daily and argues that it is important to send relevant information to receivers to maintain their interest. Both 'Marques de Riscal' 
and 'Barahonda' wineries highlighted the importance to utilize SM in order to create and build brand image to all the stakeholders, "the sales will arrive later from the image 272 created" (Remaud and Couderc, 2006). 'Barahonda' and 'La Purísima' wineries 273 remarked the importance of networks to communicate with remote consumers for 274 exporter industries. A loss of opportunities to create relationships with consumers were 275 found (Quinton and Harridge-March, 2008; Degen and Thach, 2015; Forbes et al., 276 2015).

277 All the wineries that engaged in SM provided a link to the webpage of the winery; 278 however, only $3.36 \%$ linked to an email to contact someone at the winery. This number 279 is down from $4.6 \%$ in 2013.

280 Seventy-two percent of the wineries used their SM interactions as a simple publicity 281 tool. All showed awards and medals won and the label imagery, all associated with the brand, as millennials appreciate; however, none of them revealed the alcohol content of their wines (i.e. nothing about the product) (Fiore et al., 2016). The latter could be a concern, since information regarding alcohol content is something millennials look for when making purchasing decisions (Atkin and Thach, 2012). Furthermore, other details such as pricing or environmental practices were also missing from SM sources; while again these were previously identified as important for millennials when choosing a wine (Atkin and Thach, 2012).

289 More than half of the wineries (52.17\%) presented quite technical information that was not immediately of use for the general public, let alone understandable. Lockshin et al. (2006) and Capitello et al. (2014) have previously remarked that wine professionals need to recognise that consumers may find it difficult to comprehend technical information, and that the wine professionals perhaps need to spend more time listening to the language of the typical low-involvement wine drinkers, especially millennials. Wine professionals may need to rethink the way in which they communicate with their customers about wine in the light of the inaccuracies of what is said; the idiosyncratic interpretation of commonly-used terms; and the scepticism some consumers have about the jargon used to describe wine (Charters and Pettigrew, 2006; Marks, 2015; Zurbita, 2012).

300 In the 2013 part of this study $77.1 \%$ of the wineries indicated that their SM is managed 301 by a dedicated person, a role dedicated to a single person within the company that 302 increased in prevalence to $86.2 \%$ in 2016 . It has to be clarified that regardless of being a 303 dedicated role, it is not the sole role of that person within the winery business - the 
same person has several functions to fulfil. This multiskilling requirement does not mean that SM management skills are not considered as an important skill of communication. On the contrary, the increase in dedicated persons acting as the SM manager revealed that wineries are treating this function more and more as a professional one. When interviewing the representatives of the key wineries, they unanimously declared that having a dedicated communications manager to manage their SM and other communication was vitally important. Furthermore, they all recognized the need for a clear communication plan. Some of the representatives of the wineries interviewed for this study recognized that many of their contemporary companies commenced their SM activities with no clear objective of communication; while others remarked the importance to create an overarching image for all the wineries in the region and general society (Bouquet, 2012; Forbes et al., 2015). Wineries might frequently check and update the content and interactions of their SM, and adjust them accordingly to fit their general consumers' profile (Lockshin and Corsi, 2012). Table 3 has confirmed the first of the hypotheses that the research study sought to test: $\mathrm{H}_{1}$ : Most of the wineries are starting in SM without a well-defined strategy.

\subsection{Significant business variables to have SM}

324 In light of the Chi-square analysis for significant variables, relationships $\left(\chi^{2}<0.95\right)$ 325 between size of the winery $(\mathbf{S})$, exportation $(\mathbf{E})$, webpage $(\mathbf{W})$, origin $(\mathbf{O})$, type of wine 326 (T) and "have SM" were found in 2013. In 2016, only to have a webpage (W), the 327 origin (O) and the type of wines (T) produced were significant to have a SM (Table 4).

328 In 2013, a strong relationship (typified and corrected residues t.c.r. $=2.5$ ) between the 329 non-use of SM and being a small winery $(<250 \mathrm{Hl})$ was found. These results reinforced 330 the fact that larger the wineries, higher is the adoption of Web 2.0 (Rehm et al., 2013; 331 Kolb and Thach, 2016; Mariani et al., 2012).

332 In 2013, wineries exporting to international markets were more probable (t.c.r. $=2.5$; $333 p$-value $=0.001)$ to have a presence on SM. Further significance analysis revealed that 334 is also highly probable that exporting wineries maintain a webpage. These exporting 335 wineries are highly probable to use SM to provide general ready-to-use information 336 with regards to their wines, the brand, and the company to potential customers in their 
337 own country or abroad. A strong relationship ( $p$-value $=0.000)$ for both periods 338 (t.c.r. ${ }_{2013}=5.2$ and t.c.r. $2016=7.4$ ) was found in operation both SM and a webpage.

339 In 2013, it was very probable that wineries producing only red wine (t.c.r. $=2.3$ ) had

340 SM. Three years later (in 2016) the uptake of SM by wineries had broadened to also 341 include a high probability that white wine producing wineries (t.c.r. $=2.2$ ) were utilizing 342 SM. In 2013, there was a significant interaction (t.c.r. $=2.8$ ) between wineries that 343 operated in the largest red wine producing areas and the use of SM (Wilson and 344 Quinton, 2012). Whereas wineries from small viticulture areas producing both red and 345 rosé wines were less likely (t.c.r.=-3.0) to use SM. By 2016, the interaction between 346 wineries that operated in the largest red wine producing areas and the use of SM 347 increased to t.c.r. $=3.5$; while wineries in the largest white wine producing areas had also 348 become very likely to utilize SM (t.c.r.=2.2).

352 The significance analysis concludes a shifting pattern in the use of SM by the wineries 353 over this three year period.

354 The principle aim of the logistic regression analysis was to run an overall model with 355 the significant variables obtained in 2013 and 2016, and to describe the determinant 356 variables associated with operating SM. The original dataset in the logit model included 357 the following variables in 2013: viticulture origin area (O); type of wine/s produced 358 (T); exports (E); size of the winery (S) and the existence of a winery webpage (W). For 359 2016, the dataset in the logit model included the variables: viticulture origin area (O); 360 type of wine/s produced (T) and the existence of a winery webpage $(\mathbf{W})$.

361 The analysis was developed in two steps. The first model in the output is a null model, 362 that is, a model with no predictors, a univariate logistic regression analysis. The second 363 model output the determinant variables to have SM ( $p$-value $<0.05)$. The odds ratio in 3642013 revealed that being a winery in a small viticulture area producing red and rosé 365 wines versus a winery in a large and specialized red wine region decreases the log odds 366 of having SM by 0.029 . Being a winery with webpage versus not webpage winery 367 increases the log odds of SM by 18.979 (Table 5). The overall test for the 2013 model 368 includes these predictors. The chi-square value of 43.847 with a $p$-value of 0.000 , less 369 than 0.005 tells that the model as a whole fits significantly better than an empty model 370 (a model with no predictors). The deviance of the overall model $\mathrm{G}=223.853$ in 
371 comparisons of nested models is significant. The presence of a webpage (W) and the 372 origin (O) provides significant variables in the overall model equation to have SM in 3732013 ( $p$-value $=0.000$; $p$-value $=0.005)$. The outcome overall logit model for 2013 is:

374

$$
\ln \frac{p_{i}}{1-p_{i}}=-0.384+2.943 W-3.549 O
$$

375

The odds ratio in 2016 revealed that being a winery with a webpage versus a none webpage winery increases the log odds of SM by 28.693 (Table 5).

377

378

Note to typesetter: Insert Table 5 here

379

380

The overall test for the 2016 model includes this predictor. The chi-square value of 71.873 with a $p$-value of 0.000 , less than 0.005 tells that the model as a whole fits significantly better than an empty model (a model with no predictors). The deviance of the overall model $\mathrm{G}=187.001$ in comparisons of nested models is significant. The presence of a webpage $(\mathbf{W})$ provides significant variable in the overall model equation to have SM in 2016 ( $p$-value $=0.000)$. The outcome overall logit model for 2016 is:

386

$$
\ln \frac{p_{i}}{1-p_{i}}=-3.42+3.357 \mathrm{~W}
$$

387

388 The results indicate that to have a webpage is the single most determinant factor linked to operating a SM site (Velikova et al., 2011). Although $81.0 \%$ of wineries have a webpage, these observations revealed that not all of them use this tool to its best potential (Bruwer and Wood, 2005).

392 It can be concluded that operating a webpage, would be a requirement in order for wineries to utilise SM. Hence, the digital environment influences the winery to have

394 SM. $37.8 \%$ of the wineries with webpage in 2013 , and the $20.8 \%$ in 2016 , do not have 395 SM.

396 Additionally, the increase in wineries that utilise SM in 2016 compared to 2013 has

397 reduced the number of determinant variables to have a SM. The marked increase (from $39867 \%$ in 2013 to nearly $100 \%(98.9 \%)$ in 2016) of wineries that export their wines made 399 exportation an unsuitable determinant factor. However, not all of the wineries make 400 similar use of SM.

401 Table 4 and 5 have confirmed the second of the hypotheses that the research study 402 sought to test: $\mathrm{H}_{2}$ : Wineries engaging in SM have a "digital" history. 


\subsection{Targeting wine millennial consumers}

405 The wineries unanimously thought that SM is the best media to access to younger 406 consumers. Nevertheless, wine culture has not achieved its position amongst younger 407 audiences who however, are the principal users of SM, especially the generations 408 known as millennials (Matellanes, 2014). Wineries must focus their strategies on 409 millennials; be positioned through all sales channels, especially in e-commerce (Portelli, 410 2016). The representatives of the wineries interviewed for this study expressed their 411 concern that wine consumption among Spanish youth is lower than in countries like the 412 UK or the USA. Only $5.5 \%$ of the Spanish youth drink wine on a regular basis (OEMV, 413 2014). The wineries' representatives indicated that they sponsor events, promote brand 414 images and design wines to encourage young consumers. To this effect, wine festivals 415 are organized each year, like the Madrid based "enofestival", which is organised by 416 wine large producers not only to increase the wine consumption among millennials but 417 also to impart some of the traditional Spanish wine culture to the nation's youth. Other 418 wineries include this approach onto the product design by the use of vibrant colours, 419 branding, bottle design, etc. to be attractive to millennial consumers. Such as the "San 420 Millán of Codorniu" brand. "Fancy gulps" like "Iglup" have been designed by the 421 "Grandes Vinos" brand that meant to be a low graduation "slurp of fresh grapes" 422 oriented to millennial consumers. These innovative products emerge with an offer for 423 millennials that includes an attractive image and creative communication with the 424 quality of traditional Spanish wineries.

425 None of the winery representatives interviewed, recognized the need to undertake any 426 SM practices that specifically appeal to millennial wine consumers. The wineries 427 acknowledged that SM is itself a young people's media although they do not consider 428 targeting strategies or segmentation of SM users to ensure and enrich communications 429 with millennials. To start with, in order to reach millennials, wineries could post on SM 430 over the weekends and between eight and ten in the mornings, because millennials are 431 proven to check their SM when they wake up (Wilson and Quinton, 2012). They should 432 also select the proper SM outlets (Leigon, 2011) and adapt to SM language and create a 433 dialogue with younger users (Laverie et al., 2011). It is relevant to enhance a 434 personalised communication with and to their SM community users (Dolan et al., 2016; 435 Degen and Thach, 2015). 
436 Interviews confirmed the third hypothesis that the research study sought to test: $\mathrm{H}_{3}$ :

437 Wineries engaging in SM do not segment SM on targeting wine consuming millennials.

438

4394 Conclusions, Applications and Future Research areas

440 Conclusions

441 A digital environment like a webpage was found to be a strong determinant to have SM 442 used by the wineries. An explosion in the use of SM over the three years between 2013 443 and 2016 was found. The gap between digital and non-digital wineries in the sample has 444 been reduced over the same period, which was evident by the greater interest in the use 445 of SM. The profile of a digital winery in 2016 includes the utilisation of a webpage, 446 SM, on-line services and e-commerce. The need and the opportunity were the main 447 factors, in 2013 to use SM by the wineries. A need to look for new markets and 448 millennial consumers forced the wineries to implement different tools. The opportunity 449 of resources drove the wineries to use SM. The larger wineries, with more resources and 450 opportunities, were more likely to have started using SM in 2013. Three years later, the 451 large and daily increase of the use of SM and follower's interest originated an explosion 452 in the use of SM by wineries. Moreover, wineries use SM so as not to lose the 453 opportunities of this communication tool but most of the wineries are starting in SM 454 without a well-defined strategy. The wineries do not segment and target their SM. 455 Targeting would allow wineries to focus on task groups increasing the efficiency of 456 each action. In the era of communication with plenty of information available to focus 457 on the target group SM communication strategy could be optimized. SITE must be 458 encouraged by the wineries for competitiveness and an efficient communication.

459 S-egmentation- of the target niche of consumers.

460 I-dentification- of the proper social media where the niche of consumers are.

461 T-ools- of communication implementation for the niche of consumers and SM.

462 E-valuation- of the engagement and response of consumers.

463

464 Practical implications for wineries:

465 - Well-defined and continuous SM actions will allow wineries to locate the 466 winery's public image into SM.

467 - Digital technologies can be considered an important driver that affects and 468 impacts firm decisions related to improving a winery's marketing management. 
- Accomplish the winery's own education in SM management and possibilities as a marketing tool that can improve the efficiency on SM.

471

472

473

474

475

476

477

478

479

480

481

482

483

484

485

486

487

488

489

490

491

492

493

494

495

496

497

498

499

500

501

502

- The target group for SM output must be millennials, but also other consumers and distributors that use SM.

- Segmentation and targeting on SM can improve the effectiveness of the winery SM activities, but also the competitiveness of the brand in the wine industry.

- Wineries might use big-data analysis for SM segmentation, targeting and positioning.

Future Research Areas:

There is a need to classify wine SM due to customer segmentation and to identify the best SM to focus the winery SM activities regarding its wine sales. Moreover the characterization of SM millennial users by interests, motivation to use SM and purchases would be interesting. Researchers might hold focus groups with users of the various SM sites in order to gather in-depth feedback on their involvement in these media.

It would be useful to analyse the number of followers that become consumers of the brand and measure the level of conversion of awareness to action. Evidences of the consumers' responses for different type of SM interactions are needed and develop skills to measure the marketing impact of SM. Moreover, not only economic criteria but social and environmental benefits need to be evaluated of the use of SM.

It would also be important to explore new functionalities of SM and applications to reach task customers and develop marketing tools applied to SM.

\section{References}

- Atkin, T. and Thach, L. (2012), "Millennial wine consumers: Risk perception and information search", Wine Economics and Policy, Vol. 1, pp. 54-62.

- Barber, N., Almanza, B. and Donovan, J. (2006), "Motivational factors of gender, income and age on selecting a bottle of wine", International Journal of Wine Marketing, Vol. 18 No. 3, pp. 218-232.

- Barber, N. (2010), “Green” wine packaging: targeting environmental consumers", International Journal of Wine Business Research, Vol. 22 No. 4, pp. $423-444$.

- Bauer, C., Greve, G., Hopf, G. (2011), "Online targeting und controlling”, Gabler Verlag, Springer Fachmedien Wiesbaden GmbH, Wiesbaden. 
- Blasius, J. and Brandt M. (2010), "Representativeness in Online Surveys through Stratified Samples”, Bulletin de Methodologie Sociologique, Vol. 107, pp. 5-21.

- Bruwer, J. and Li, E. (2007), "Wine-Related Lifestyle (WRL) Market Segmentation: Demographic and Behavioural Factors", Journal Of Wine Research, Vol. 18, No. 1, pp. 5-21.

509

510

- Bruwer, J. and Wood, G. (2005), "The Australian online wine-buying consumer: Motivational and behavioural perspectives", Journal of Wine Research, Vol. 16, pp. 193-211.

- Bouquet, P. (2012), "Social media marketing in the American and French wine industry in 2011", available at: http//ablesocial.com/market-research (last accessed 25 March, 2017).

- Capitello, R., Agnoli, L., Begalli, D. and Codurri, S. (2014). "Social media strategies and corporate brand visibility in the wine industry", EuroMed Journal of Business, Vol. 9 No. 2, pp. 129-148.

- Charters, S. and Pettigrew, S. (2006), "Product involvement and the evaluation of wine quality", Qualitative Market Research: An International Journal, Vol. 9 No. 2, pp. 181-193.

- Charters, S., Thach, L., Fountain, J., Kolyesnikova, N., Ritchie, C., Dodd, T., Fish, N., Herbst, F. and Terblanche, N. (2011), "Generation Y and sparkling wines: a cross-cultural perspective", International Journal of Wine Business Research, Vol. 2 No. 2, pp. 161-175.

- Cialdini, R.B. and Goldstein, N.J. (2004), "Social influence: compliance and conformity”, Annual Review of Psychology, Vol. 55, pp. 591-621.

- Degen, W. and Thach, L. (2015), "7 Tips to Work Successfully with Wine Distributors", available at: http://www.winebusiness.com/news/?go=getArticle\&dataid=155929, ， (last accessed 25 March, 2017).

- Dolan, R., Conduit, J., Fahy, J. and Goodman, S. (2016), "Facebook for Wine Brands: An Analysis of Strategies for Facebook Posts and User Engagement Actions", in $9^{\text {th }}$ Academy of Wine Business Research Conference, 17 February 2016, Adelaide, Australia. 
- Espejel, J., Fando, C. and Flavián, C. (2011), “Antecedents of consumer commitment to a PDO wine: an empirical analysis of Spanish consumers", Journal of Wine Research, Vol. 22 No 3, pp. 205-225.

- Fiore, M., Vrontis, D., Silvestri, R. and Contò, F. (2016), "Social Media and Societal Marketing: A Path for a Better Wine?", Journal of Promotion Management, Vol. 22, pp. 268-279.

- Forbes, S.L., Goodman, S. and Dolan, R. (2015), "Use of social media in the Australian and New Zealand wine industries", Australian and New Zealand Grapegrower and Winemaker, Vol. 95.

- Gokcekus, O. and Finnegan, C.M. (2013), "Did the Great Recession change the regional reputation premium for wine in the US?", Wine Economics and Policy, Vol. 2, pp. 27-32.

- Halls, J., Binney, W. and O'Mahoney, G.B. (2004), “Age related motivational segmentation of wine consumption in a hospitality setting", International Journal of Wine Marketing, Vol. 16 No. 3, pp. 29-43.

- Hussain, M., Cholette, S. and Castaldi, R.M. (2008), "An analysis of globalization forces in the wine industry", Journal of Global Marketing, Vol. 21, pp. 33-47.

- Kilian, T., Hennigs, N. and Langner, S. (2012), "Do Millennials read books or blogs? Introducing a media usage typology of the internet generation", Journal of Consumer Marketing, Vol. 29 No. 2, pp. 114-124.

- Koetsier, J. (2013), "Facebook: 15 million businesses, companies, and organizations now have a Facebook page", available at: http://venturebeat.com/2013/03/05/facebook-15-million-businesses-companiesand-organizations-now-have-a-facebook-page/ (last accessed 25 March, 2017).

- Kolb, D. and Thach, L. (2016), "Analyzing German winery adoption of Web 2.0 and social media", Journal of Wine Research, Vol. 27 No.3, pp. 226-241.

- Labroo, A.A., Dhar R., Schwarz, N. (2008), "Of frog wines and Frowning Watches: Semantic Priming, Perceptual Fluency, and Brand Evaluation", Journal of Consumer Research, Vol. 34 No.6, pp. 819-831.

- Laverie, D.A., Humphrey, W., Velikova, N., Dodd, T.H. and Wilcox, J.B. (2011). "Building wine brand communities with the use of social media: a conceptual model". Proceedings of the 6th AWBR International Conference, 2011, 9-10. 
- Leigon, B. (2011), "Grape/Wine Marketing with new media and return of the boomer", Practical Winery \& Vineyard Journal, available at: http://www.practicalwinery.com/winter2011/marketing1.htm (last accessed 25 March, 2017).

Lockshin, L. and Corsi, A.M. (2012), "Consumer behaviour for Wine 2.0: A review since 2003 and future directions", Wine Economics and Policy, Vol. 1, pp. 2-23.

- Lockshin, L., Jarvis, W., d'Hauteville, F. and Perrouty, J.P. (2006), “Using simulations from discrete choice experiments to measure consumer sensitivity to 
- OEMV. (2014). Report: "Consumo de vino en España y el vino en las redes sociales". OEMV.

604 - Olsen, J., Thach, L. and Nowak, L. (2007), "Wine for my generation: exploring 605 how US wine consumers are socialized to wine", Journal of Wine Research, Vol. 18 No. 1, pp. 1-18.

608

609

610

611

612

613

614

615

616

617

618

619

620

621

622

623

624

625

626

627

628

629

630

631

632

633

634

- Orth, U.R. (2005), "Consumer personality and other factors in situational brand choice variation", Brand Management, Vol. 13 No. 2, pp. 115-133.

- Pate, S.S. and Adams, M. (2013), "The influence of social networking sites on buying behaviors of millennials", Atlantic Marketing Journal, Vol. 2 No. 1, pp. 7-17.

- Portelli, F. (2016), "Las exigencias del nuevo marketing del vino" in: XI Foro Internacional del Vino "Construyendo el futuro". Ciudad de Mendoza, Argentina.

- Quinton, S. and Harridge-March, S. (2008), "Trust and online wine purchasing: insights into UK consumer behavior", International Journal of Wine Business Research, Vol. 20, pp. 68-85.

- Rehm, J., Rehm, M. X., Shield, K. D., Gmel, G. and Solé, A. G. (2013), "Consumo de alcohol, dependencia alcohólica, trastornos relacionados con el alcohol en España. Impacto de los tratamientos de la dependencia alcohólica", Adicciones: Revista de socidrog alcohol, Vol. 25 No. 1, pp. 11-18.

- Remaud, H. and Couderc, J. P. (2006), "Wine business practices: a new versus old wine world perspective", Agribusiness, Vol. 22, pp. 405-416.

- Reyneke, M., Berthon, P.R., Pitt, L.F. and Parent, M. (2011), "Luxury wine brands as gift: ontological and aesthetic perspectives", International Journal of Wine Business Research, Vol. 23 No. 3, pp. 250-278.

- Stieglitz, S., Dang Xuan, L., Bruns, A. and Neuberger, C. (2014), “Social Media Analytics”, Business \& Information Systems Engineering, Vol. 6 No. 2, pp. 8996.

- Storchmann, K. (2012), "Wine economics", Journal of Wine Economics, Vol. 7 No. 1, pp. 1-33.

- Szolnoki, G., Taits, D., Nagel, M. and Fortunato, A. (2014), "Using social media in the wine business: an exploratory study from Germany", International Journal of Wine Business Research, Vol. 26, pp. 80-96. 
635 - Teagle, J., Mueller, S. and Lockshin, L. (2010), "How do Millennial wine 636 attitudes and behavior differ from older generations?", in 5th International 637 Academy of Wine Business Research Conference Proceedings, Auckland, New 638 Zealand, 2010, Academy of Wine Business Research.

639 - Thach, L. and Lease, T. (2014), “Exploring the Impact of Social Media Practices 640 on Wine Sales in U.S. Wineries", in AWBR 8th International Conference, Geisenheim, Germany, 2014, Academy of Wine Business Research.

642

643

- Thach, L. and Olsen, J. (2006), "Market segment analysis to target young adult wine drinkers", Agribusiness, Vol. 22 No. 3, pp. 307-322.

- Thach, L. (2010), “Wine blogs: expressing diverse wine opinions in a new realm of online wine relationship marketing", in 5th International Academy of Wine Business Research Conference Proceedings, Auckland, New Zealand, 2010, Academy of Wine Business Research.

- Thach, L. and Rosenberg, J. (2011), "Current \& Future Trends in Social Media for Wine Tourism", in 2011 Wine Tourism Conference, Napa, California, Nov. 16-17. 2011.

- Velikova, N., Wilcox, J. B. and Dodd, T. H. (2011), "Designing Effective Winery Websites: Marketing-Oriented versus Wine-Oriented Websites”. 6th AWBR International Conference, 2011, Bordeaux Management School, France.

- Viberti A., Massagliaa S. and Borra, D. (2014), "Wine, wineries \& internet: How new media are used by producers of Langhe and Roero", in 37th World Congress of Vine and Wine and 12th General Assembly of the OIV, 4 November 2014, OIV.

- Vinography. (2016), "Social Media and the Wine Industry: A New Era", available at: http://www.vinography.com/archives/2012/02/social_media_and the wine ind u.html (last accessed 25 March, 2017).

- Web empresa 2.0. (2015), "La herramienta analítica de la nueva era. (Web log post)", available at: http://www.webempresa20.com/blog/herramientas-deanalitica-web.html (last accessed 6 April 2016).

- Wilson, D. and Quinton, S. (2012), "Let's talk about wine: Does Twitter have value?", International Journal of Wine Business Research, Vol. 24, pp. 271-286. 
1

2

3

4

5

6

7

8

9

10

11

12

13

14

15

16

17

18

19

20

21

22

23

24

25

26

27

28

29

30

31

32

33

34

35

36

37

38

39

40

41

42

43

44

45

46

47

48

49

50

51

52

53

54

55

56

57

58

59

60
667 - Zickuhr, K. (2010), “Generations Online Report. Pew Internet Research", 668 available at: http://pewinternet.org//Reports/2010/Generations$669 \quad$ 2010/Overview.asp (last accessed 25 March, 2017).

670 - Zurbita, I. (2012), "Las redes sociales y Vinos de España”, Master Thesis 671 Marketing, Johns Hopkins University. 
Table 1. Business and social media management variables, classified by categorical and quantitative for the 196 wineries sampled in Old World region of Castilla and Leon in 2013/2016

\begin{tabular}{lll}
\hline Variables & $\begin{array}{l}\text { Business } \\
\text { (obtained through survey) }\end{array}$ & $\begin{array}{l}\text { Social media management } \\
\text { (obtained through online observation) }\end{array}$ \\
\hline Categorical & Location & Products \\
& Year of foundation & Map and directions \\
Company format & Languages \\
& Webpage & Content \\
& E-commerce & Link to webpage \\
& Social media & Link to email \\
& Organic production & Target public \\
& Wine tourism & Institutional or product publicity \\
& Direct sales & Professional site management \\
& Type of wines & Forum \\
& & \\
Quantitative & Size & Followers \\
& Shareholders & Actualizations in 1 month \\
& Distribution & Number click "I like it" \\
\hline
\end{tabular}

Table 2. Profile of wineries in the Spanish wine producing region of Castilla and Leon, percentage $(\%)$ and distribution $(\mathrm{n}=196)$

\begin{tabular}{|c|c|c|c|c|c|c|}
\hline \multicolumn{2}{|c|}{ Wineries variables } & \multirow{2}{*}{$\begin{array}{c}\text { Percentage } \\
\mathbf{2 0 1 3 - 2 1 0 6}\end{array}$} & Wineries variables & & \multicolumn{2}{|c|}{ Percentage } \\
\hline Year of & Before 1949 & & Company format & Natural person & 2013 & $\begin{array}{r}2016 \\
5.1\end{array}$ \\
\hline \multirow[t]{5}{*}{ foundation } & 1950-1965 & 4.6 & & Public Limited company & & 16.3 \\
\hline & $1966-1980$ & 6.6 & & Private Limited company & & 64.3 \\
\hline & 1981-1995 & 26.0 & & Community property & & 7.2 \\
\hline & $1996-2010$ & 57.7 & & Cooperative & & 7.1 \\
\hline & After 2010 & 1.5 & Shareholders & Only owner & & 62.2 \\
\hline Annual & Less 250 & 32.2 & & $1-10$ & & 36.8 \\
\hline production & $250-990$ & 12.2 & & $11-25$ & & 0.5 \\
\hline \multirow[t]{3}{*}{ (HI) } & $1,000-2,990$ & 24.5 & & $26-50$ & & 0.5 \\
\hline & $3,000-10,000$ & 19.4 & Distribution & National & 32.2 & 1.1 \\
\hline & More 10,000 & 11.7 & & International & 67.8 & 98.9 \\
\hline \multirow[t]{5}{*}{ Type of wine/s } & Red only & 26.0 & Web page & Yes & 80.1 & 81.0 \\
\hline & White only & 28.6 & & No & 19.9 & 19.0 \\
\hline & Red and rosé & 19.9 & Social Media & Yes & 42.8 & 61.0 \\
\hline & Red and white & 0.5 & & No & 57.2 & 39.0 \\
\hline & Red, white and rosé & 25.0 & & & & \\
\hline
\end{tabular}

Table 3. Distribution and percentage of social media variables measured in a sample of 196 wineries in a Spanish wine region of Castilla and Leon

\begin{tabular}{ll|lll}
\hline Social media items & Percentage & & Social media items & Percentage \\
\cline { 3 - 4 }
\end{tabular}


Table 4. Chi-square analysis for significant variables relationships $\left(\chi^{2}<0.95\right)$ between business variables and "have" or "not have" social media

\begin{tabular}{|c|c|c|}
\hline \multirow[t]{2}{*}{ Business variables } & \multicolumn{2}{|c|}{ p-value } \\
\hline & 2013 & 2016 \\
\hline Size of the winery (S) & $0.016^{*}$ & 0.056 \\
\hline Origin $(\mathbf{O})$ & $0.006 * *$ & $0.000 * *$ \\
\hline Type of wine/s (T) & $0.022 *$ & $0.002 * *$ \\
\hline Webpage (W) & $0.000 * *$ & $0.000 * *$ \\
\hline Exports (E) & $0.001 * *$ & 0.259 \\
\hline
\end{tabular}

Table 5. Significance analyses of the logistic model in two steps: Wald Forward. Logistic regression analyses for 2013 and 2016 significant business variables

\begin{tabular}{lcccccc}
\hline \multirow{2}{*}{ Business variables } & \multicolumn{3}{c}{$\mathbf{2 0 1 3}$} & \multicolumn{2}{c}{$\mathbf{2 0 1 6}$} \\
\cline { 2 - 7 } & Coef. & $\boldsymbol{p}$-value & Odds ratio & Coef. & $\boldsymbol{p}$-value & Odds ratio \\
\hline Origin $(\mathbf{O})$ & -3.542 & $0.005^{* *}$ & 0.029 & & & \\
Webpage $(\mathbf{W})$ & 2.943 & $0.000^{* *}$ & 18.979 & 3.357 & $0.000^{* *}$ & 28.693 \\
Constant & -0.384 & & & -3.42 & & \\
\hline
\end{tabular}

$* p$-value $<0.05, * * p$-value $<0.01$ 